\title{
Origin of Unusually High Fluorescence Anisotropy of 3-Hydroxyflavone in Water: Formation of Probe-Solvent Cage-like Cluster
}

\author{
Sinjan Das ${ }^{\mathrm{a}}$, Suman Chakrabarty ${ }^{\mathrm{b}}$ and Nitin Chattopadhyay ${ }^{\mathrm{a},{ }^{*}}$ \\ ${ }^{a}$ Department of Chemistry, Jadavpur University, Kolkata - 700 032, India \\ ${ }^{b}$ Department of Chemical, Biological \& Macromolecular Sciences, S. N. Bose National Centre for Basic \\ Sciences, Kolkata - 700 106, India \\ *Corresponding author: Fax: 91-33-2414-6584 \\ E-mail: nitin.chattopadhyay@yahoo.com
}

\section{Supporting Information}

Table S1. Determination of stabilization energies of 3HF-water clusters.

\begin{tabular}{|c|c|c|c|c|c|}
\hline $\begin{array}{l}\text { Opt. energy } \\
\text { of } 3 \mathrm{HF} \text { alone } \\
\mathrm{E}_{3 \mathrm{HF}} \text { (a.u.) }\end{array}$ & $\begin{array}{c}\text { No. of } \\
\text { water } \\
\text { molecules }\end{array}$ & $\begin{array}{l}\text { Opt. energy of } \\
\text { 3HF-water } \\
\text { clusters } \mathrm{E}_{\mathrm{A}} \\
\text { (a.u.) }\end{array}$ & $\begin{array}{c}\text { Single point } \\
\text { energy of } \\
\text { isolated water- } \\
\text { clusters } E_{B} \text { (a.u.) }\end{array}$ & $\begin{array}{c}\text { Stabilization } \\
\text { energy } \\
\Delta \mathrm{E}=\mathrm{E}_{\mathrm{A}}-\mathrm{E}_{\mathrm{B}}- \\
\mathrm{E}_{3 \mathrm{HF}} \text { (a.u.) }\end{array}$ & $\begin{array}{c}\text { Stabilization } \\
\text { energy } \\
(\Delta \mathrm{E})(\mathrm{kcal} / \mathrm{mol})\end{array}$ \\
\hline \multirow{8}{*}{ 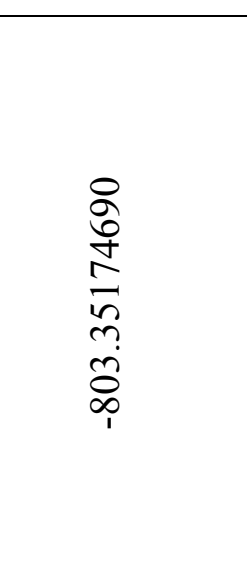 } & 0 & -803.35174690 & -- & 0 & 0 \\
\hline & 1 & -879.80157993 & -76.44200803 & -0.00782 & -4.91 \\
\hline & 2 & -956.25365725 & -152.88956617 & -0.0123 & -7.72 \\
\hline & 3 & -1032.70715447 & -229.34098956 & -0.0144 & -9.04 \\
\hline & 4 & -1109.15824432 & -305.79218603 & -0.0143 & -8.97 \\
\hline & 5 & -1185.60919505 & -382.24262697 & -0.0148 & -9.29 \\
\hline & 6 & -1262.06639494 & -458.70215455 & -0.0125 & -7.84 \\
\hline & 7 & -1338.51782564 & -535.15357207 & -0.0125 & -7.84 \\
\hline
\end{tabular}



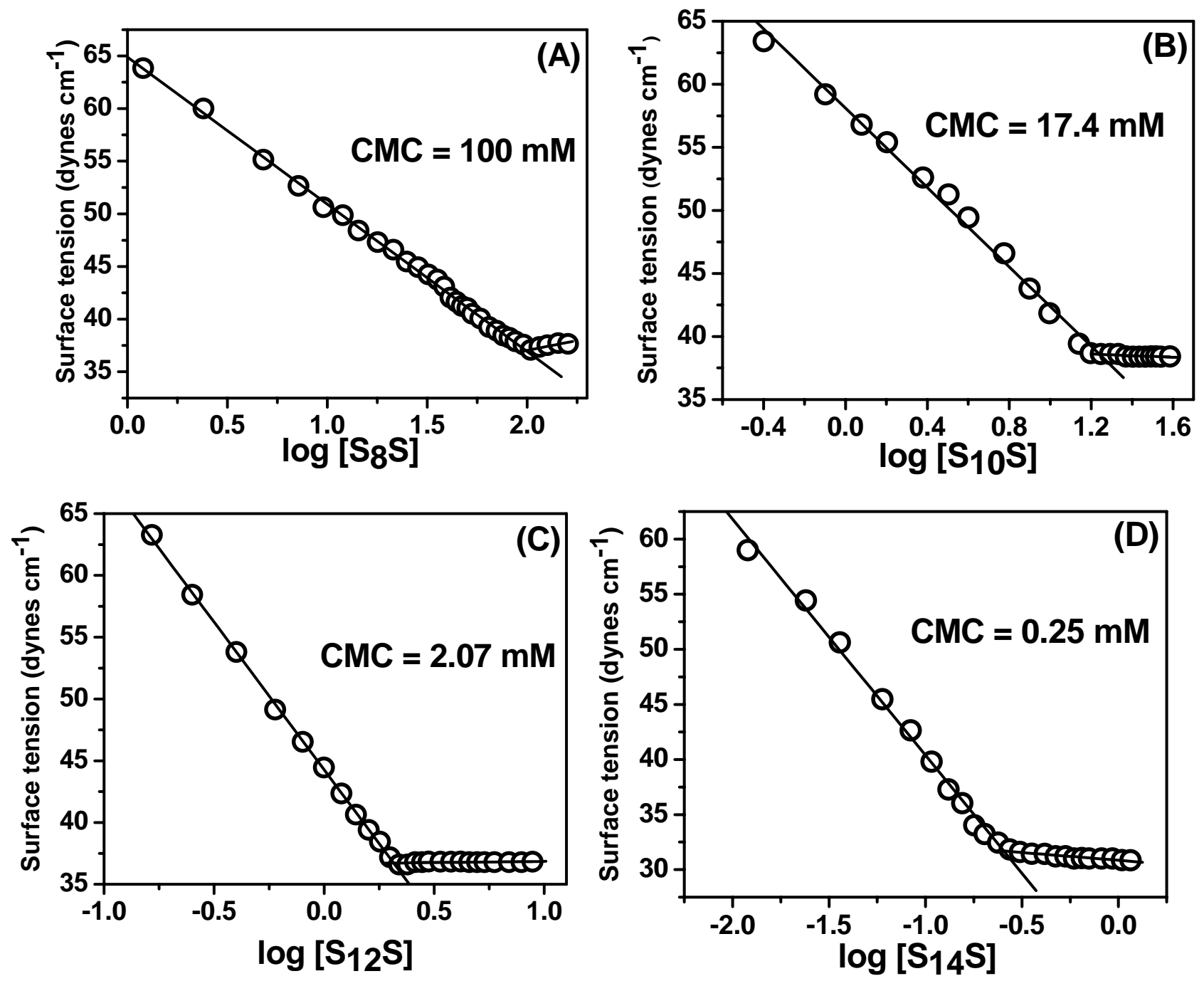

Figure S1. Plots for the determination of CMCs of (A) $\mathrm{S}_{8} \mathrm{~S}$, (B) $\mathrm{S}_{10} \mathrm{~S}$, (C) $\mathrm{S}_{12} \mathrm{~S}$ and (D) $\mathrm{S}_{14} \mathrm{~S}$ in phosphate-citrate buffer at $\mathrm{pH}=3.5$.

Table S2. Determined CMC values of the investigated $\mathrm{S}_{\mathrm{n}} \mathrm{S}$ systems in buffer at $\mathrm{pH}=3.5$.

Surfactants From the steady state fluorescence From surface tension anisotropy measurement of $3 \mathrm{HF}(\mathrm{mM})$ measurement $(\mathrm{mM})$

\begin{tabular}{ccc}
\hline $\mathrm{S}_{8} \mathrm{~S}$ & $106 \pm 10$ & $100 \pm 10$ \\
$\mathrm{~S}_{10} \mathrm{~S}$ & $22 \pm 5$ & $17.4 \pm 2$ \\
$\mathrm{~S}_{12} \mathrm{~S}$ & $2 \pm 0.2$ & $2.07 \pm 0.2$ \\
$\mathrm{~S}_{14} \mathrm{~S}$ & $0.31 \pm 0.05$ & $0.25 \pm 0.05$ \\
\hline
\end{tabular}



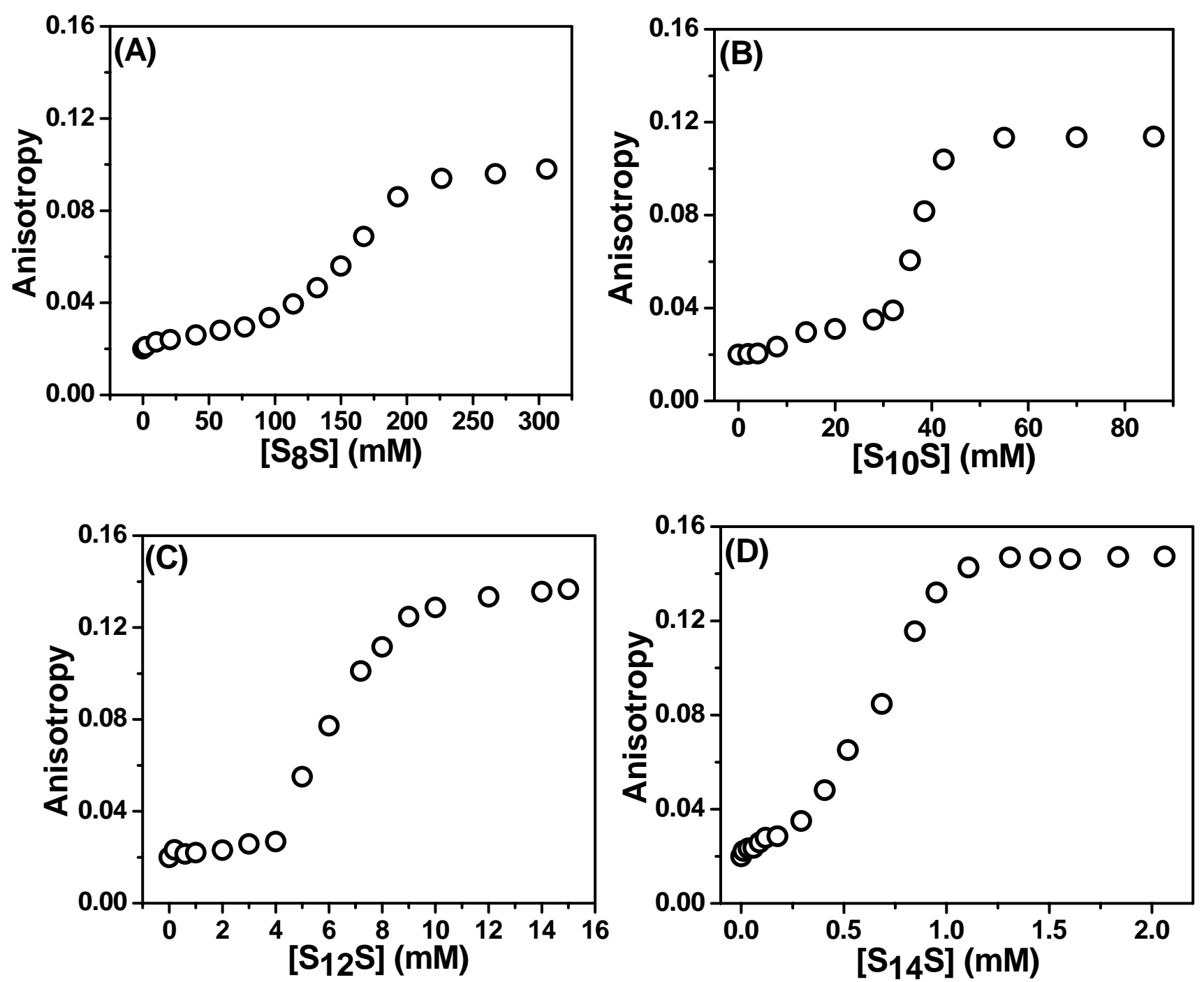

Figure S2. Fluorescence anisotropy of $3 \mathrm{MF}$ as a function of concentration of (A) $\mathrm{S}_{8} \mathrm{~S}$, (B) $\mathrm{S}_{10} \mathrm{~S}$, (C) $\mathrm{S}_{12} \mathrm{~S}$ and (D) $\mathrm{S}_{14} \mathrm{~S}$. $\lambda_{\mathrm{ex}}=355 \mathrm{~nm}$ and $\lambda_{\text {monitored }}=430 \mathrm{~nm}$. [3MF] $\approx 4 \mu \mathrm{M}$. An average of 20 consistent anisotropy values is presented for every concentration of $\mathrm{S}_{\mathrm{n}} \mathrm{Ss}$. 

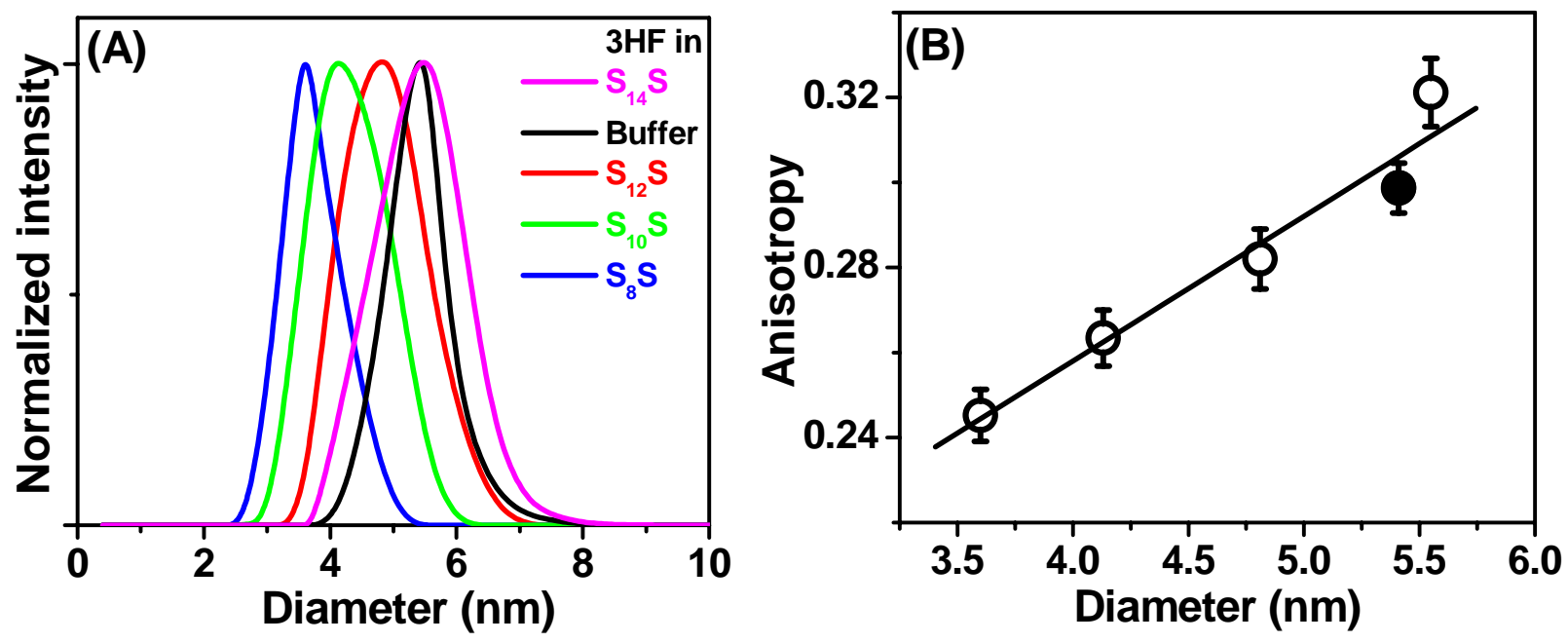

Figure S3. (A) Normalized size (diameter) distribution of 3HF in buffer and in $\mathrm{S}_{8} \mathrm{~S}(296 \mathrm{mM}), \mathrm{S}_{10} \mathrm{~S}(75$ $\mathrm{mM}), \mathrm{S}_{12} \mathrm{~S}(12 \mathrm{mM})$ and $\mathrm{S}_{14} \mathrm{~S}(1.5 \mathrm{mM})$. [3HF] $\approx 4 \mu \mathrm{M}$. (B) The variation of fluorescence anisotropy of 3HF (open circles) with its effective dimensions in different $\mathrm{S}_{\mathrm{n}} \mathrm{S}$ media. Filled circle denotes the anisotropy of the same in the buffer medium.

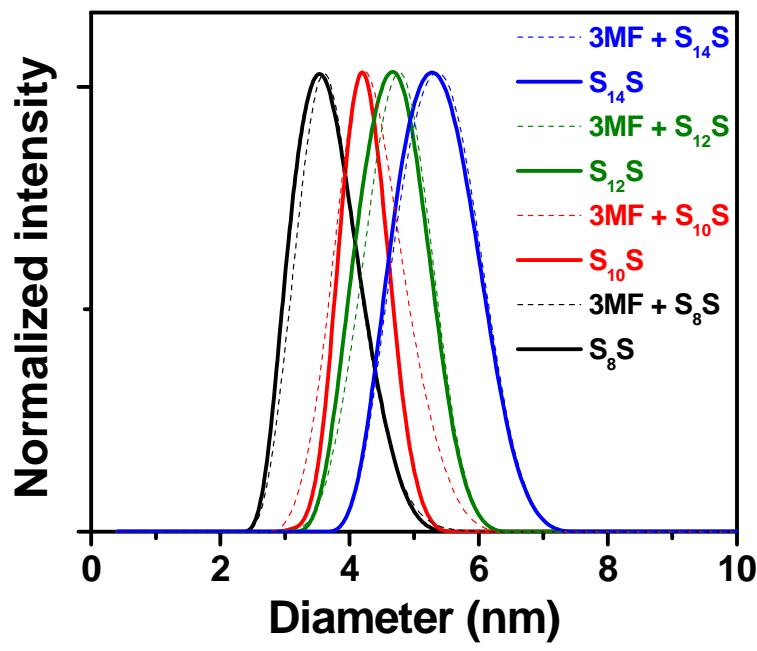

Figure S4. Normalized size (diameter) distribution of $\mathrm{S}_{8} \mathrm{~S}(296 \mathrm{mM}), \mathrm{S}_{10} \mathrm{~S}(75 \mathrm{mM}), \mathrm{S}_{12} \mathrm{~S}(12 \mathrm{mM})$ and $\mathrm{S}_{14} \mathrm{~S}(1.5 \mathrm{mM})$ micelles (bold lines) and the same in the presence of $3 \mathrm{MF}$ (dashed lines). [3MF] $\approx 4 \mu \mathrm{M}$. 
Table S3. Hydrodynamic diameters of micelles, 3MF-bound micelles and the steady state fluorescence anisotropy values of $3 \mathrm{MF}$ in different micellar media.

\begin{tabular}{cccc}
\hline Medium & $\begin{array}{c}\text { Hydrodynamic diameter of } \\
\text { micelles }( \pm 0.4 \mathrm{~nm})\end{array}$ & $\begin{array}{c}\text { Hydrodynamic diameter of } \\
\text { 3MF-bound micelles } \\
( \pm 0.4\end{array}$ & $\begin{array}{c}\text { Steady state fluorescence } \\
\text { anisotropy of 3MF }( \pm \\
0.005)\end{array}$ \\
\hline Buffer & - & - & 0.020 \\
$\mathrm{~S}_{8} \mathrm{~S}(296 \mathrm{mM})$ & 3.5 & 3.6 & 0.098 \\
$\mathrm{~S}_{10} \mathrm{~S}(75 \mathrm{mM})$ & 4.2 & 4.2 & 0.114 \\
$\mathrm{~S}_{12} \mathrm{~S}(12 \mathrm{mM})$ & 4.7 & 4.8 & 0.137 \\
$\mathrm{~S}_{14} \mathrm{~S}(1.5 \mathrm{mM})$ & 5.3 & 5.4 & 0.147 \\
\hline
\end{tabular}



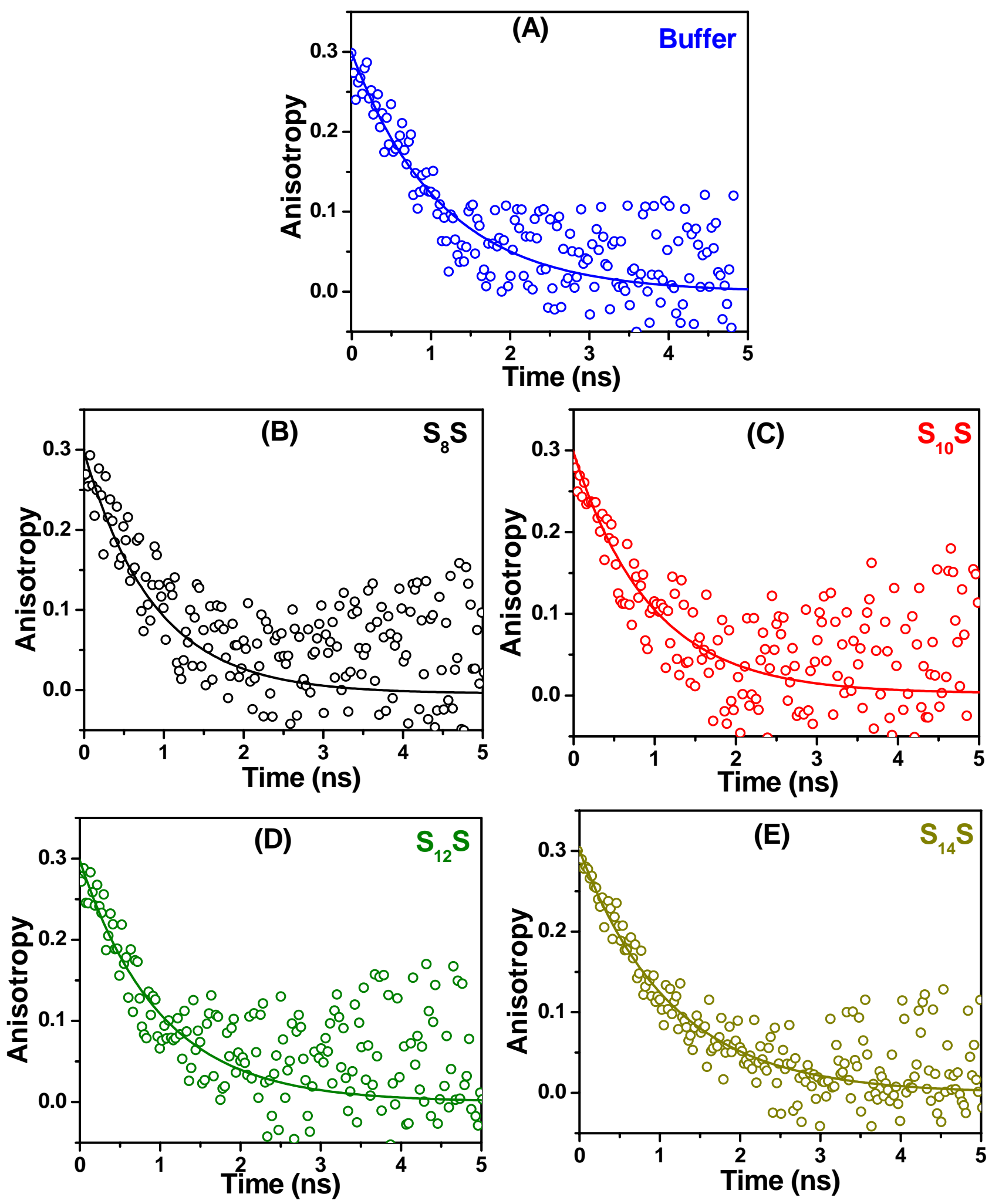

Figure S5. Time resolved FA decays of 3HF in different media as depicted in the legends. The solid lines denote the corresponding fits. 

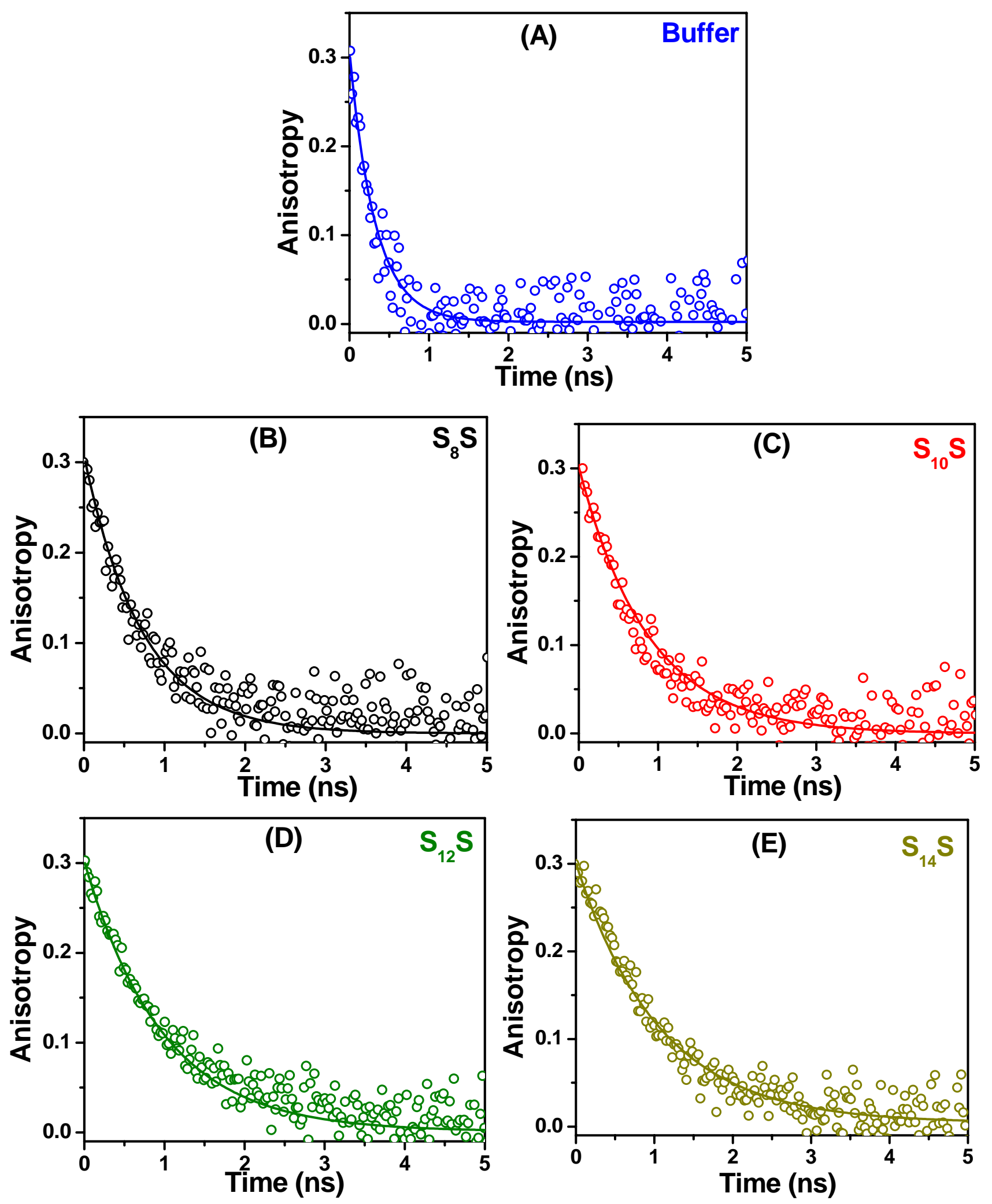

Figure S6. Time resolved FA decays of 3MF in different media as depicted in the legends. The solid lines denote the corresponding fits. 